\begin{tabular}{|c|c|c|}
\hline \multirow{3}{*}{$\begin{array}{r}\text { Case Reports in } \\
\text { Gastroenterology }\end{array}$} & \multirow{2}{*}{\multicolumn{2}{|c|}{ Case Rep Gastroenterol 2015;9:285-290 }} \\
\hline & & \\
\hline & $\begin{array}{l}\text { DOI: 10.1159/000438746 } \\
\text { Publisnea onithe: August 6, } 2015\end{array}$ & $\begin{array}{l}\text { (c) } 2015 \text { S. Karger AG, Basel } \\
1662-0631 / 15 / 0092-0285 \$ 39.50 / 0 \\
\text { www.karger.com/crg }\end{array}$ \\
\hline & \multicolumn{2}{|c|}{$\begin{array}{l}\text { This is an Open Access article licensed under the terms of the Creative Common } \\
\text { Attribution-NonCommercial } 3.0 \text { Unported license (CC BY-NC) (www.karger.com/OA } \\
\text { license), applicable to the online version of the article only. Distribution permitted for non } \\
\text { commercial purposes only. }\end{array}$} \\
\hline
\end{tabular}

\title{
Long-Term Maintenance of Complete Response after Sorafenib Treatment for Multiple Lung Metastases from Hepatocellular Carcinoma
}

\author{
Eisuke Katafuchi Yuko Takami Yoshiyuki Wada Masaki Tateishi \\ Tomoki Ryu Kazuhiro Mikagi Hideki Saitsu \\ Department of Hepato-Biliary-Pancreatic Surgery, Clinical Research Institute, National \\ Hospital Organization Kyushu Medical Center, Fukuoka, Japan
}

\author{
Key Words \\ Hepatocellular carcinoma · Sorafenib · Complete response - Lung metastases · Liver . \\ Chemotherapy
}

\begin{abstract}
Sorafenib is an effective treatment for unresectable hepatocellular carcinoma $(\mathrm{HCC})$ characterized by disease stabilization. However, the response rates are very low $(<9 \%)$, and a complete response is rarely achieved. We report an extremely rare case of a HCC patient with multiple lung metastases treated with sorafenib who achieved a complete response for a long period. A 77-year-old woman was diagnosed with chronic hepatitis C in 1990. In 2007, a HCC detected in the liver was treated with percutaneous ethanol injection therapy. Subsequently, recurrence of HCC in the liver was treated with microwave coagulonecrotic therapy in 2010. In April 2011, a computed tomography (CT) scan revealed innumerable multiple metastases spread diffusely in both lungs. Tumor marker levels were extremely high $[\alpha-$ fetoprotein (AFP) $76,170 \mathrm{ng} / \mathrm{ml}$, lens culinaris agglutinin-reactive fraction of AFP $7.5 \%$, des- $\gamma$ carboxyprothrombin (DCP) 63,400 $\mathrm{mAU} / \mathrm{ml}$. Sorafenib was administered at a reduced dose of $400 \mathrm{mg} /$ day because of old age. Four months after sorafenib treatment, AFP and DCP had decreased to within normal levels, and the multiple lung metastases had disappeared. Currently, sorafenib is administered at a reduced dose of $400 \mathrm{mg} /$ day, and the complete response has been maintained for 48 months.

(c) 2015 S. Karger AG, Basel
\end{abstract}

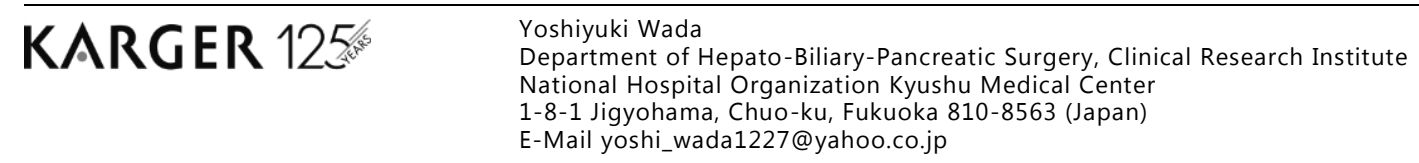


Katafuchi et al.: Long-Term Maintenance of Complete Response after Sorafenib Treatment for Multiple Lung Metastases from Hepatocellular Carcinoma

\section{Introduction}

Hepatocellular carcinoma (HCC) is one of the most common cancers in the world [1]. Sorafenib, an oral molecular-targeted drug, has become the standard therapy for advanced HCC (i.e., extrahepatic metastases, unresectable or not eligible for locoregional therapy) [2]. Sorafenib is a multiple kinase inhibitor which affects tumor proliferation and angiogenesis by inhibiting Raf-1, B-Raf kinase, vascular endothelial growth factor receptor 1, 2 and 3, platelet-derived growth factor receptor $\beta$, Flt-3 and c-KIT 2 .

Two recent double-blind randomized phase III trials, the Sorafenib HCC Randomized Protocol (SHARP) [2] and the Asian-Pacific Trial [3], have shown improvement in overall survival after sorafenib treatment; in addition, sorafenib is believed to be particularly effective for distant metastasis. However, the partial response was low at $2-5 \%$, and there were no cases of complete response (CR) among the 449 patients treated with sorafenib in these trials. Therefore, sorafenib has been considered as a disease stabilizer.

Herein, we report a very rare case treated with sorafenib for HCC with multiple lung metastases resulting in a CR that has been maintained for 48 months.

\section{Case Report}

A 77-year-old Japanese female was diagnosed with chronic hepatitis C in 1990. A HCC $(13 \times 10 \mathrm{~mm})$ was detected in segment $7 / 8$ on a computed tomography (CT) scan and treated with percutaneous ethanol injection therapy in April 2007. Subsequently, recurrence of the HCC $(23 \times 13 \mathrm{~mm})$ was observed in December 2010 in the same segment, and microwave coagulation therapy was performed. In April 2011, a chest X-ray image and CT scan revealed multiple lung metastases (fig. 1a). No brain or bone metastases could be detected.

Laboratory test results at the time of diagnosis were as follows: albumin $2.9 \mathrm{~g} / \mathrm{dl}$, aspartate aminotransferase $30 \mathrm{IU} / \mathrm{l}$, alanine aminotransferase $15 \mathrm{IU} / \mathrm{l}$, total bilirubin $0.5 \mathrm{mg} / \mathrm{dl}$ and prothrombin international normalized ratio 1.05. The patient had good reserve liver function with a Child-Pugh score of 6 (Child-Pugh class A) and did not have any ascites or findings of encephalopathy. Tumor markers such as $\alpha$-fetoprotein (AFP; 76,170 ng/ml), the lens culinaris agglutinin-reactive fraction of AFP (7.5\%) and des- $\gamma$-carboxyprothrombin (DCP; 63,400 mAU/ml) were elevated. Sorafenib administration was initiated at a reduced dose of $400 \mathrm{mg} /$ day, because of the patient's advanced age and low body mass index (BMI) of 19.7 .

After 4 months of sorafenib administration, the tumor markers decreased to normal levels (AFP $7.5 \mathrm{ng} / \mathrm{ml}$, DCP $30 \mathrm{mAU} / \mathrm{ml}$ ), and the metastatic lung lesions had disappeared (fig. 1b). We considered that the patient had achieved a CR according to the RECIST evaluation. The patient continues to be treated with sorafenib at a reduced dose of $400 \mathrm{mg} /$ day without adverse effects and is still maintaining a CR.

\section{Discussion}

The present patient represents a rare case involving multiple lung metastases, confirmed on the basis of imaging and tumor marker levels, who achieved a CR after treatment with sorafenib. Furthermore, it was unusual because the patient has maintained this CR for 48 months and has continued sorafenib treatment without adverse effects. There are $2 \mathrm{im}$ - 
Katafuchi et al.: Long-Term Maintenance of Complete Response after Sorafenib

Treatment for Multiple Lung Metastases from Hepatocellular Carcinoma

portant points to note in our case: (1) the achievement of a CR and (2) long-term maintenance of the CR.

Sorafenib is usually used for disease stabilization, and its response rate is $<9 \%$. In a retrospective study that compared sorafenib responders (CR and partial response) and nonresponders (stable disease, progressive disease and nonprogressive disease), multiple lung metastases were frequently observed in responders to sorafenib [4]. Therefore, sorafenib seems to be effective in the treatment of extrahepatic metastasis, especially lung metastasis. Shiba et al. [5] reported that significant factors in their 18 Japanese cases involving a CR were sex (female), low body weight $(<59 \mathrm{~kg}$ ), early clinical stage and use of a small initial dose. The clinical characteristics of the 12 reported cases and our case that achieved a CR as a result of sorafenib treatment are detailed in table 1 [6-17]. There were 6 (46\%) lung metastasis cases. The data suggest that sorafenib is useful in the treatment of lung metastasis. Intrahepatic tumor stage seems unrelated to the rate of CR, because 8 out of 13 cases were at stage T3-4. AFP levels decreased by $>20 \%$ in all cases presented in table 1, but 9 out of 13 cases had an initial AFP level of $\geq 400 \mathrm{ng} / \mathrm{dl}$. This indicates that the AFP response is a good prognostic factor regarding CR and also that it is possible to achieve a CR regardless of the initial AFP levels.

The number of males and females was 11 and 2, respectively. Interestingly, only 4 out of 13 cases had commenced treatment with sorafenib at a dose of $400 \mathrm{mg} /$ day (table 1). Elucidation of the characteristics of HCC patients who attained a CR after sorafenib treatment allows prediction of efficacy and survival outcome before the initiation of treatment. However, populations of patients who have achieved a CR are too small for definitive conclusions to be made. Further evaluation in future clinical studies is required.

Five out of 13 cases had maintained a CR for $>10$ months (table 1). Two among these 5 cases exhibited multiple lung metastases. These findings suggest that a patient who has multiple lung metastases can be expected to achieve a long-term CR. It has been controversial as to whether or not sorafenib treatment should be continued after the diagnosis of a CR. In a previous study, 188 patients who had undergone sorafenib monotherapy were analyzed, and it was reported that patients who received sorafenib for $>90$ days showed a favorable outcome [18]. In fact, 3 out of 5 long-term CR patients detailed in table 1 continued sorafenib administration. Consequently, continuation of sorafenib treatment may be important in maintaining a long-term CR. The tolerability of sorafenib must be a limitation regarding continuation of the treatment. Actually, in most patients, the initial dose of sorafenib had been reduced because of adverse effects (table 1). In the GIDEON study [19], the advantage of using a sorafenib dose of $800 \mathrm{mg} /$ day had been demonstrated. However, a randomized control study carried out by the SOraFenib Italian Assessment (SOFIA) group compared initial doses of $400 \mathrm{mg} /$ day and $800 \mathrm{mg} /$ day. It was found that the therapy group that received the lower dose of $400 \mathrm{mg} /$ day had a longer median survival time [20]. In our case, we started sorafenib treatment at a reduced dose of $400 \mathrm{mg} /$ day because the patient was elderly and had a low BMI. As mentioned, the patient has been maintained on the same dose for $>3$ years without adverse effects.

In conclusion, multiple lung metastases and low body weight seem to be the characteristics required for the achievement of a long-term CR. The reason for the superiority regarding the use of a reduced initial dose of $400 \mathrm{mg} /$ day remains unclear. However, our case suggests the possibility of achieving a long-term CR as a result of continuation of treatment with this dose of sorafenib. The limitation of this report is that the periods over which a CR was sustained in the cases detailed in table 1 might be underestimates; this is because many of the patients would have continued to maintain their CR after the date on which their data were 
Katafuchi et al.: Long-Term Maintenance of Complete Response after Sorafenib

Treatment for Multiple Lung Metastases from Hepatocellular Carcinoma

published. It remains important to accumulate and carefully analyze long-term CR cases in order to fully investigate the prognostic factors regarding sorafenib.

\section{Conclusion}

We have reported a case of innumerable multiple lung metastases of HCC keeping a CR for 48 months.

\section{Disclosure Statement}

The authors declare no conflicts of interest.

\section{References}

1 Bruix J, Sherman M: Management of hepatocellular carcinoma: an update. Hepatology 2011;53:1020-1022.

2 Llovet JM, Ricci S, Mazzaferro V, et al: Sorafenib in advanced hepatocellular carcinoma. N Engl J Med 2008;359:378-390.

3 Cheng AL, Kang YK, Chen Z, et al: Efficacy and safety of sorafenib in patients in the Asia-Pacific region with advanced hepatocellular carcinoma: a phase III randomised, double-blind, placebo-controlled trial. Lancet Oncol 2009;10:25-34.

4 Arao T, Ueshima K, Matsumoto K, et al: FGF3/FGF4 amplification and multiple lung metastases in responders to sorafenib in hepatocellular carcinoma. Hepatology 2013;57:1407-1415.

5 Shiba S, Okusaka T, Ikeda M, et al: Characteristics of 18 patients with hepatocellular carcinoma who obtained a complete response after treatment with sorafenib. Hepatol Res 2014;44:1268-1276.

-6 Chelis L, Ntinos N, Souftas V, et al: Complete response after sorafenib therapy for hepatocellular carcinoma in an HIV-HBV co infected patient: possible synergy with HAART? A case report. Med Oncol 2011;28(suppl 1):S165-S168.

7 So BJ, Bekaii-Saab T, Bloomston MA, et al: Complete clinical response of metastatic hepatocellular carcinoma to sorafenib in a patient with hemochromatosis: a case report. J Hematol Oncol 2008;1:18

8 Sacco R, Bargellini I, Gianluigi G, et al: Complete response for advanced liver cancer during sorafenib therapy: case report. BMC Gastroenterol 2011;11:4.

-9 Yeganeh M, Finn RS, Saab S: Apparent remission of a solitary metastatic pulmonary lesion in a liver transplant recipient treated with sorafenib. Am J Transplant 2009;9:2851-2854.

10 Kim MS, Jin YJ, Lee JW, et al: Complete remission of advanced hepatocellular carcinoma by sorafenib: a case report. World J Gastrointest Oncol 2013;5:38-42.

11 Inuzuka T, Nishikawa H, Sekikawa A, et al: Complete response of advanced hepatocellular carcinoma with multiple lung metastases treated with sorafenib: a case report. Oncology 2011;81(suppl 1):152-157.

$\checkmark 12$ Hagihara A, Teranishi Y, Kawamura E, et al: A complete response induced by 21-day sorafenib therapy in a patient with advanced hepatocellular carcinoma. Intern Med 2013;52:1589-1592.

13 Mizukami H, Kagawa T, Arase Y, et al: Complete response after short-term sorafenib treatment in a patient with lymph node metastasis of hepatocellular carcinoma. Case Rep Oncol 2012;5:380-384.

-14 Kee KM, Hung CH, Wang JH, et al: Serial changes of clinical parameters in a patient with advanced hepatocellular carcinoma with portal vein thrombosis achieving complete response after treatment with sorafenib. Onco Targets Ther 2014;7:829-834.

15 Kudo M, Ueshima K: Positioning of a molecular-targeted agent, sorafenib, in the treatment algorithm for hepatocellular carcinoma and implication of many complete remission cases in Japan. Oncology 2010;78(suppl 1):154-166.

16 Shiozawa K, Watanabe M, Ikehara T, et al: Sustained complete response of hepatocellular carcinoma with portal vein tumor thrombus following discontinuation of sorafenib: a case report. Oncol Lett 2014;7:50-52. Wang SX, Byrnes A, Verma S, et al: Complete remission of unresectable hepatocellular carcinoma treated with reduced dose of sorafenib: a case report. Target Oncol 2010;5:59-63.

18 Kudo M, Ueshima K, Arizumi T: Real-life clinical practice with sorafenib in advanced hepatocellular carcinoma: a single-center experience. Dig Dis 2012;30:609-616.

19 Lencioni R, Kudo M, Ye SL, et al: First interim analysis of the GIDEON (Global Investigation of therapeutic DEcisions in hepatocellular carcinoma and Of its treatment with sorafeNib) non-interventional study. Int ] Clin Pract 2012;66:675-683. 


\section{Case Reports in \\ Gastroenterology}

\begin{tabular}{l|l}
\hline \multicolumn{2}{l}{ Case Rep Gastroenterol 2015;9:285-290 } \\
\hline DOI: 10.1159/000438746 & $\begin{array}{l}\text { ○ 2015 S. Karger AG, Basel } \\
\text { www.karger.com/crg }\end{array}$ \\
\hline
\end{tabular}

Katafuchi et al.: Long-Term Maintenance of Complete Response after Sorafenib

Treatment for Multiple Lung Metastases from Hepatocellular Carcinoma

20 Iavarone M, Cabibbo G, Piscaglia F, et al: Field-practice study of sorafenib therapy for hepatocellular carcinoma: a prospective multicenter study in Italy. Hepatology 2011;54:2055-2063.

Table 1. Complete response in HCC patients treated with sorafenib

\begin{tabular}{|c|c|c|c|c|c|c|c|c|c|c|c|c|c|c|}
\hline First author & $\begin{array}{l}\text { Age, } \\
\text { years/ } \\
\text { sex }\end{array}$ & Etiology & $\begin{array}{l}\text { Intrahepatic } \\
\text { tumor stage } \\
\text { (T stage) }\end{array}$ & $\begin{array}{l}\text { Extrahepatic } \\
\text { spread }\end{array}$ & $\begin{array}{l}\text { Time to } \\
\text { cessation }\end{array}$ & Time to CR & $\begin{array}{l}\text { Administra- } \\
\text { tion period } \\
\text { after CR, } \\
\text { months }\end{array}$ & $\begin{array}{l}\text { Reason of } \\
\text { cessation }\end{array}$ & $\begin{array}{l}\text { CR } \\
\text { sustained } \\
\text { period, } \\
\text { months }\end{array}$ & $\begin{array}{l}\mathrm{AFP} \\
\mathrm{ng} / \mathrm{ml}\end{array}$ & $\begin{array}{l}\text { AFP- } \\
\text { L3, } \\
\%\end{array}$ & $\begin{array}{l}\mathrm{DCP} \\
\mathrm{mAU} / \mathrm{ml}\end{array}$ & $\begin{array}{l}\text { Sorafenib } \\
\text { initial } \\
\text { dose, } \\
\text { mg/day }\end{array}$ & $\begin{array}{l}\text { Mainte- } \\
\text { nance } \\
\text { dose, } \\
\text { mg/day }\end{array}$ \\
\hline Chelis [6] & $69 / \mathrm{M}$ & HBV, HIV & 3 & lymph node & none & 10 months & - & - & 6 & - & - & - & 800 & 400 \\
\hline So [7] & $78 / \mathrm{M}$ & $\begin{array}{l}\text { Hemochro- } \\
\text { matosis }\end{array}$ & -3 & lung & 6 months & 5 months & 1 & clinical & 6 & 13,599 & - & - & 800 & 800 \\
\hline Sacco [8] & $84 / \mathrm{M}$ & $\mathrm{HCV}$ & 3 & none & none & 6 months & - & - & 6 & 353 & - & - & 800 & 800 \\
\hline$\overline{\text { Yeganeh [9] }}$ & $54 / \mathrm{M}$ & HBV & 0 & lung & none & 18 months & - & - & 7 & 1.3 & - & - & 800 & 200 \\
\hline Kim [10] & $66 / \mathrm{M}$ & alcohol & 4 & lymph node & 12 months & 6 months & 6 & financial & 8 & 2,795 & - & - & 800 & 400 \\
\hline Inuzuka [11] & $76 / \mathrm{F}$ & $\mathrm{HCV}$ & 0 & lung & 4 months & 3 months & 1 & liver dysfunction & 8 & 6,952 & - & 187 & 400 & 400 \\
\hline Hagihara [12] & $65 / \mathrm{M}$ & $\mathrm{HCV}$ & 0 & lung & 21 days & 3 months & 0 & ascites & 8 & 55,607 & - & 11,302 & 400 & 400 \\
\hline Mizukami [13] & 69/M & $\mathrm{HCV}$ & 0 & lymph node & 11 days & 3 months & 0 & $\begin{array}{l}\text { hand foot } \\
\text { syndrome }\end{array}$ & 9 & 25.1 & 22.8 & 65 & 800 & 400 \\
\hline Kee [14] & $74 / \mathrm{M}$ & unknown & 4 & none & none & 9 months & - & - & 10 & 33,058 & - & - & 800 & 200 \\
\hline Kudo [15] & $68 / \mathrm{M}$ & HBV & 3 & lung & none & 2 months & - & - & 12 & 18,775 & 68.1 & 26,021 & 800 & 400 \\
\hline Shiozawa [16] & $68 / \mathrm{M}$ & $\mathrm{HCV}$ & 4 & none & 2.4 years & 2 years & 4 & patient's request & 16 & 4,773 & 60.5 & 17,400 & 800 & 400 \\
\hline Wang [17] & $74 / \mathrm{M}$ & $\mathrm{HCV}$ & 4 & none & 8 months & 8 months & 0 & nausea, vomiting & 16 & 3,300 & - & - & 400 & 400 \\
\hline Our case & $77 / \mathrm{F}$ & $\mathrm{HCV}$ & 0 & lung & none & 3 months & - & - & 45 & 76,170 & 7.5 & 63,400 & 400 & 400 \\
\hline
\end{tabular}

$\mathrm{M}=$ Male, $\mathrm{F}=$ female, $\mathrm{HBV}=$ hepatitis B virus, $\mathrm{HIV}=$ human immunodeficiency virus, $\mathrm{HCV}=$ hepatitis $\mathrm{C}$ virus. 


\begin{tabular}{ll|l} 
Case Reports in & \multicolumn{2}{l}{} \\
\cline { 2 - 3 } Gastroenterology & Case Rep Gastroenterol 2015;9:285-290 & $\begin{array}{l}\text { @ 2015 S. Karger AG, Basel } \\
\text { www.karger.com/crg }\end{array}$ \\
\cline { 2 - 3 } & DOI: 10.1159/000438746 &
\end{tabular}

Katafuchi et al.: Long-Term Maintenance of Complete Response after Sorafenib Treatment for Multiple Lung Metastases from Hepatocellular Carcinoma

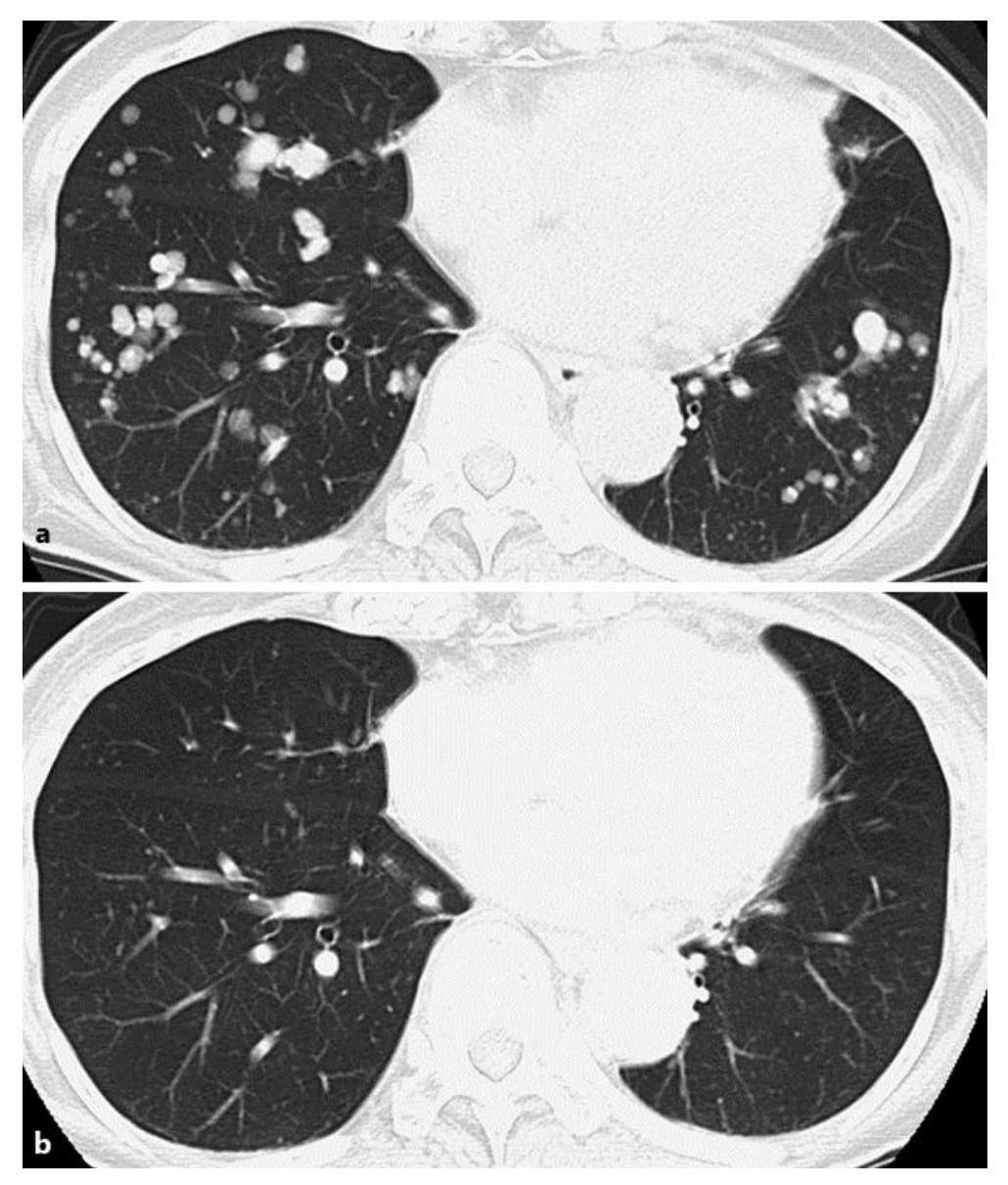

Fig. 1. Chest CT images. a CT image at the initiation of sorafenib administration. Innumerable multiple lung metastases were revealed in both lungs. b CT image 4 months after sorafenib treatment. The multiple lung metastases disappeared in both lungs after sorafenib treatment. 